\title{
Tetracycline Resistant Genes as Bioindicators of Water Pollution
}

\author{
Manal F. Abdelall, ${ }^{1}$ Safa S. Hafez, ${ }^{2}$ Maryam El. Fayad, ${ }^{2}$ Hanan A. Nour El-Din, ${ }^{1}$ Soad A. Abdallah ${ }^{2}$ \\ ${ }^{1}$ Microbial Molecular Biology Department, Agricultural Genetic Engineering Research Institute (AGERI), Agricultural \\ Research Center (ARC), Giza; ${ }^{2}$ Botany Department, Faculty of Women for Arts, Science and Education, Ain-Shams \\ University, Cairo, Egypt
}

\begin{abstract}
The current study aimed to investigate the prevalence of tetracycline resistant bacteria isolated from different water samples and the genes responsible for this resistance. Two hundred fifty isolates were isolated from different water samples from two different locations. Isolates were obtained from El-Zamalek site was $(\mathrm{n}=110)$ and from Rod El-Farag site was $(\mathrm{n}=140)$. A hundred isolates out of 250 bacterial isolates $(40 \%)$ were resistant to tetracycline at a concentration of $16 \mu \mathrm{g} / \mathrm{ml}$. Only $31(31 \%)$ were selected due to their resistance to $(32 \mu \mathrm{g} / \mathrm{ml})$ tetracycline for identification. All selected isolates were identified according to biochemical and the $16 \mathrm{~S}$ sequence techniques. The $16 \mathrm{~S}$ rDNA gene sequences of the bacterial isolates which were reported in this study were submitted to the NCBI database. Of the 31 isolates were analyzed by Polymerase Chain Reaction (PCR), results showed that $41.9 \%$ (13/31) harbored tet A gene, 74.2\% (23/31) carried tet D gene, while $12.9 \%(4 / 31)$ carried tet $\mathrm{M}$ gene. Whereas tet $\mathrm{B}$, tet $\mathrm{C}$ and tet $\mathrm{O}$ were not detected. Twenty-one isolates (67.7\%) harbored a
\end{abstract}

Correspondence: Manal Farouk M. Abdelall, Department of Microbial Molecular Biology, Agricultural Genetic Engineering Research Institute (AGERI), Agricultural Research Center (ARC), 9 Gamaa Street, 12619, Giza, Egypt.

Tel.: (202) 010-09647-399.

Fax: (202) 3573-1574.

E-mail:manalfm@gmail.com; maanlfm@ageri.sci.eg

Acknowledgements: The authors would thank all participants and their parents.

Key words: Water pollution; Tetracycline-resistant bacteria; tet resistant genes; 16S rDNA; Bioindicators.

Conflict of interests: The Authors declare no potential conflict of interests.

Received for publication: 14 August 2019

Accepted for publication: 9 January 2020.

${ }^{\circ}$ Copyright: the Author(s), 2020

Licensee PAGEPress, Italy

Journal of Biological Research 2020; 93:8490

doi:10.4081/jbr.2020.8490

This article is distributed under the terms of the Creative Commons Attribution Noncommercial License (by-nc 4.0) which permits any noncommercial use, distribution, and reproduction in any medium, provided the original author(s) and source are credited. single tet gene, five isolates $(16.1 \%)$ harbored two different tet genes while three isolates $(9.7 \%)$ harbored three different tet genes. Moreover, two isolates were free from any tested tet genes.

\section{Introduction}

Water is the means through which bacteria as well as antibiotics resistant bacteria (its related resistant genes) is carried to the human body. ${ }^{1}$ Research has revealed that the use of antibiotics for treatment of human and animal diseases and for agricultural usages is growing dramatically. ${ }^{2}$ This resulted in the development of bacteria that is antibiotic-resistant which led to the ineffectiveness of some antibiotics in treating infections and led to serious health problems. ${ }^{3}$ Studies show that antibiotic-resistant bacteria are found in drinking water, wastewater and other sources in rural areas. ${ }^{4}$ Pathogenic and other microbes have the ability to resist antibiotics. ${ }^{5,6}$ Attempts to treat wastewater through biological processes have led to the increase of such microbes and other multidrug- resistant organisms. ${ }^{7,8}$ The fact that chlorination reduces the presence of microorganisms in drinking water has been confirmed in research; however, some microorganisms are antibioticresistant which means that they sometimes survive the treatment process of drinking water. ${ }^{9}$ The availability of antibiotic-resistant pathogenic microorganisms is considered a threat to public health which necessitates the reduction or the elimination of such microorganisms. ${ }^{3}$ The lowest dose of chlorination $\left(15 \mathrm{mg} \mathrm{Cl} \mathrm{Cl}_{2}\right.$ $\mathrm{min} / \mathrm{L}$ ) led to a complete deactivation of bacteria. ${ }^{10}$ However, almost $80 \%$ of tetracycline resistant genes resisted chlorination. Chlorination failed to control antimicrobial resistance. Therefore, more attention should be paid to the possible jeopardy of the availability of antibiotic resistant genes in water even after chlorination which was found to be ineffective. ${ }^{11}$

Antibiotic resistance is a common and a major public health problem that is found worldwide. ${ }^{12}$ It has been for years considered a clinical health issue; however, recent research has revealed that other non-clinical factors contributed to the spread of Antibiotic Resistant Genes (ARGs), which are globally found in natural environments. ${ }^{13}$ Horizontal Gene Transfer (HGT) is commonly found in water environments. ${ }^{14}$ The environmental dissemination of ARGs is thought to be mediated by integrons. ${ }^{15}$ The high level of integrons and ARGs in water environments is linked to the presence of anthropogenic activities and the release of antibiotics and resistant genes. ${ }^{16,17}$

After the application of tetracyclines had extensively spread, resistance to them by pathogenic bacteria started to occur. About 40 kinds of tetracycline resistance factors have been reported ${ }^{3,18}$ and classified into the following groups, i) Energy-dependent membrane-associated efflux proteins, which disseminate tetracy- 
cline out of the cell; ii) Ribosomal protection proteins, which interact with the ribosome and disrupt the tetracycline binding site; and iii) Tetracycline inactivation enzymes.

Several studies have examined tetracycline resistant (tet) genes in different environments. ${ }^{5}$ Resistant genes which encode ribosomal protection and efflux proteins have been found in various bacterial groups. Also, there is available literature about tet genes and their dissemination. ${ }^{19}$ They are A, B, C, D, E, G, K, L, M, O, S, Q and $\mathrm{X} .{ }^{20}$ Among the various resistant tet genes, the tet $\mathrm{A}$, tet $\mathrm{B}$, tet $\mathrm{C}$, tet $\mathrm{D}$, tet $\mathrm{E}$, tet $\mathrm{G}$, tet $\mathrm{Q}$ and tet $\mathrm{X}$ are reported in Gram-negative bacteria. Whereas, the tet $\mathrm{K}$, tet $\mathrm{L}$, tet $\mathrm{M}$, tet $\mathrm{O}$, and tet $\mathrm{S}$ are significantly found in the Gram-positive bacteria. ${ }^{21}$

In order to understand the ecology of antibiotic resistance in environments, it is essential to track the antibiotic resistant genes in commensal and pathogenic bacteria, as well as in the environment. One of the models for studying the ecology of antibiotic resistance could be the genes with resistance to tetracyclines. ${ }^{22}$

Therefore, the main target of this study was to detect tetracycline resistant genes (tet $\mathrm{A}$, tet $\mathrm{B}$, tet $\mathrm{C}$, tet $\mathrm{D}$, tet $\mathrm{M}$ and tet $\mathrm{O}$ ) in bacteria of aquacultural origin in order to save time, effort and cost of the routine methods for the detection of pathogenic microorganisms in fresh water sources.

\section{Materials and Methods}

\section{Sample Collection}

Water samples were collected during the summer of 2016 from two locations in Cairo city, Egypt. The areas where the samples were collected are El-Zamalek which is in the north side of the River Nile and Rod El-Farag which is located on west side of the River Nile. Samples were collected and handled following the standard methods. ${ }^{23}$

Subsurface $30 \mathrm{~cm}$ water samples were collected fifty meters away from the River Nile bank in $120 \mathrm{ml}$ sterilized screw capped brown glass labeled bottles from three different sites of each location, the bottles were opened and closed under water surface. Samples were preserved in a cooler at $10^{\circ} \mathrm{C}$. All samples were immediately transported to microbiology laboratory for bacteriological analysis and for isolation of tetracycline resistant bacteria.

\section{Bacterial Isolation and Purification}

The samples were enriched and inoculated on Lactose broth media (Difco and BBL, India) then incubated at $37^{\circ} \mathrm{C}$ for 24 hours. Then inoculum of each culture was plated on MacConkey agar (Oxoid, England) and incubated at $37^{\circ} \mathrm{C}$ for 24 hours. Only lactose fermenting colonies (smooth pink colonies) were selected. Bacterial isolates were inoculated onto nutrient agar for morphological, biochemical characterization and for tetracycline resistance test.

\section{Tetracycline Resistance Test}

The tetracycline resistance test of bacterial isolates was performed using breakpoint assays. Bacterial isolates were grown in Luria Bertani Broth (LB) (Conda, Spain) supplemented with tetracycline antibiotics (Sigma-Aldrich, USA) at two concentrations $(16 \mu \mathrm{g} / \mathrm{ml}$ and $32 \mu \mathrm{g} / \mathrm{ml})$ based on Clinical Laboratory Standards Institute ${ }^{24}$ and were incubated at $37^{\circ} \mathrm{C}, 100 \mathrm{rpm}$ overnight. The isolates that were able to resistant in these two concentrations were selected.

\section{Identification of Tetracycline Resistant Bacteria}

\section{Biochemical Characterization}

Only resistant isolates to $32 \mu \mathrm{g} / \mathrm{ml}$ were selected for the identification. They were identified based on their cell morphology as well as their Gram stain and biochemical tests according to..$^{25,26}$

\section{Molecular Characterization}

Genomic DNA was extracted from purified single colonies using Wizard ${ }^{\circledR}$ Genomic DNA Purification Kit Cat. No. A1120 (Promega, USA) following the manufacturer's instructions. The selected bacterial isolates were identified using $16 \mathrm{~S}$ rDNA sequencing as molecular tools. The 16S rDNA region from the extracted DNA of bacterial isolates was amplified using Polymerase Chain Reaction (PCR) using Applied Biosystems, 2720 Thermal Cycler. Assays were carried out in $25 \mu \mathrm{l}$ volumes containing $5 \mu 1$ of $10 \mathrm{X}$ PCR buffer (Promega), 1.5 MgCl2 (25 mM), 0.5 dNTP mixture (each 2.5 $\mathrm{mM}), 0.5 \mu \mathrm{l}$ of each Forward (F) and Reverse (R) primers $(10 \mu \mathrm{M})$, primers used were as shown in Table 1 , and 0.3 Go Taq DNA polymerase $(5 \mathrm{u} / \mu \mathrm{l}), 1 \mu \mathrm{l}$ template (approximately $20 \mathrm{ng} / \mu \mathrm{l}$ ) and 15.7 ddH2O. PCR amplification was carried out under the following conditions: initial denaturation at $94^{\circ} \mathrm{C}$ for 5 min followed by 35 cycles of denaturation at $94^{\circ} \mathrm{C}$ for 1 minute, annealing at $65^{\circ} \mathrm{C}$ for 1 minute and elongation at $72^{\circ} \mathrm{C}$ for 1 minute and final extension at $72^{\circ} \mathrm{C}$ for $7 \mathrm{~min}$. The amplified products were analyzed by electrophoresis on $1.0 \%$ agarose gel stained with ethidium bromide $(0.5 \mu \mathrm{g} / \mathrm{ml})$ and were visualized on UV gel documentation system (BioRad, USA). PCR products were purified from unincorporated PCR primers and dNTPs using QIAquick PCR Purification Kit (Qiagen, Germany), following the manufacturer's instructions. PCR products were sequenced by LGC (Applied Biosystems ${ }^{\mathrm{TM}} /$ Thermo Fisher Scientific, Germany), DNA sequence was compared to GenBank sequences using BLASTn tool to identify the best matches from Genbank based on percent sequence identity (https://blast.ncbi. nlm.nih.gov/Blast.cgi). ${ }^{27}$

\section{Detection of Tetracycline Resistant Genes by PCR}

The incidence and diversity of tetracycline resistant genes of selected thirty-one bacterial isolates were assessed by testing the presence of tetracycline (tet) resistant gene (s) that encode resistance by efflux mechanism (tet $\mathrm{A}$, tet $\mathrm{B}$, tet $\mathrm{C}$, tet $\mathrm{D}$ ) and gene (s) that encode ribosomal protection proteins (tet $\mathrm{M}$ and tet $\mathrm{O}$ ). The set of primers used for each gene is shown in (Table 1). All primers were purchased from Vivantis Co. (Selangor Darul Ehsan, Malaysia),

PCR and amplification reactions followed the same protocol as described for $16 \mathrm{~S}$ rDNA PCR. The sequence results were aligned to GenBank sequences using BLASTx tool (https://blast.ncbi.nlm. nih.gov/Blast.cgi). ${ }^{27}$

\section{Sequence Alignments and Phylogenetic Analysis}

After PCR purification, the nucleotide sequences of 31 specimens confirmed through the above-mentioned microbiological tests were sequenced in both directions. The obtained sequences from specimens as well as the sequences downloaded for both $16 \mathrm{~S}$ rDNA sequences and tet genes from GenBank for other strains of the same species were initially aligned with CLUSTAL Omega method. ${ }^{28}$ The aligned sequences were saved as fasta files that have been used as a matrix to estimate the phylogeny of the entire alignments by constructing Neighbor-Joining (NJ) tree in MEGA 7 Software. ${ }^{29}$ The phylogenetic trees were constructed and performed with 1000 bootstrap replications to evaluate the reliability of the constructions. The evolutionary distances were computed 
using the p-distance method and are in the units of the number of base differences per site.

CIRCOS configuration tool (http://circos.ca/tutorials/lessons/ configuration/distribution_and_installation/ $/)^{30}$ was used for sequence alignment of the different sequences and to illustrate nucleotide regions have a similarity to each other and sequences length.

The heat map scale tool for the similarity frequency between different sequences_was_used_(http://girke.bioinformatics.ucr.edu/ GEN242/mydoc_systemPipeRNAseq_08.html). ${ }^{31}$

\section{Results}

\section{Identification of Tetracycline Resistant Bacterial Isolates}

Two hundred fifty isolates were isolated from different water samples from two different locations. Isolates were obtained from ElZamalek site was $(n=110)$ and from Rod El-Farag site was $(n=140)$.

A hundred isolates out of 250 bacterial isolates (40\%) were resistant to $(16 \mu \mathrm{g} / \mathrm{ml})$ tetracycline. Only 31 isolates $(31 \%)$ were selected due to their resistance to $(32 \mu \mathrm{g} / \mathrm{ml})$ tetracycline for identification. All selected isolates were identified according to biochemical and $16 \mathrm{~S}$ sequence techniques.

According to morphological and biochemical characterization (Table 2), and 16S rDNA encoding genes (Table 3), selected isolates were identified. Thirty-one isolates were identified and classified to: 12 isolates $(38.7 \%)$ were Klebsiella sp., 8 isolates $(25.8 \%)$ were Kluyvera sp., 5 isolates (16.1\%) were Escherichia coli, 4 isolates (12.9\%) were Enterobacter sp., lisolate (3.2\%) were Atlantibacter hermannii and only one (3.2\%) was non-enteric isolate, Aeromonas hydrophila. These results were matching with the results of the morphological and biochemical characterization. The 16S rDNA gene sequences of 31 bacterial isolates were submitted to the NCBI database (accession No. MH266225- MH266252), accession No.MH423704-MH423705) and (accession No.MH469556), as represented in (Table 3). The phylogenetic tree showed that all resistantisolated was closely related to each other while Aeromonas hydrophila was treated as an out-group (Figure 1).

A heat map analysis and CIRCOS configuration of the identified bacterial isolate at the genus level revealed distinctions in diversity in the water samples. This map determines the similarity frequency between different sequences. As close different $16 \mathrm{~S}$

Table 1. PCR primers used for tetracycline resistant genes detection and 16S rDNA.

\begin{tabular}{|c|c|c|c|c|c|}
\hline Targetgene & Primer pair & Sequences $\left(5^{\prime}-3^{\prime}\right)$ & $\begin{array}{c}\text { Annealing } \\
\text { Temperature }\left({ }^{\circ} \mathrm{C}\right)\end{array}$ & $\begin{array}{l}\text { Amplicon size } \\
\text { (bp) }\end{array}$ & Reference \\
\hline tet $\mathrm{A}$ & $\begin{array}{l}\text { FW-A* } \\
\text { RV-A* }\end{array}$ & $\begin{array}{l}\text { GTAATTCTGAGCACTGTCGC } \\
\text { CTGCCTGGACAACATTGCTT }\end{array}$ & 52 & 917 & [48] \\
\hline tet $\mathrm{B}$ & $\begin{array}{l}\text { FW-B } \\
\text { RV-B }\end{array}$ & $\begin{array}{l}\text { TACGTGAATTTATTGCTTCGG } \\
\text { ATACAGCATCCAAAGCGCAC }\end{array}$ & 52 & 206 & [49] \\
\hline tet $\mathrm{C}$ & $\begin{array}{l}\text { FW-C } \\
\text { RV-C }\end{array}$ & $\begin{array}{l}\text { GCGGGATATCGTCCATTCCG } \\
\text { GCGTAGAGGATCCACAGGACG }\end{array}$ & 55 & 207 & {$[50]$} \\
\hline tet $\mathrm{D}$ & $\begin{array}{l}\text { FW-D } \\
\text { RV-D }\end{array}$ & $\begin{array}{l}\text { AAACCATTACGGCATTCTGC } \\
\text { GACCGGATACACCATCCATC }\end{array}$ & 55 & 787 & {$[51]$} \\
\hline tet $\mathrm{M}$ & $\begin{array}{l}\text { FW-M } \\
\text { RV-M }\end{array}$ & $\begin{array}{l}\text { GTGGACAAAGGTACAACGAG } \\
\text { CGGTAAAGTTCGTCACACAC }\end{array}$ & 50 & 406 & {$[52]$} \\
\hline tet 0 & $\begin{array}{l}\text { FW-O } \\
\text { RV-O }\end{array}$ & $\begin{array}{l}\text { AACTTAGGCATTCTGGCTCAC } \\
\text { TCCCACTGTTCCATATCGTCA }\end{array}$ & 50 & 515 & [53] \\
\hline 16S rDNA & $\begin{array}{l}27 \mathrm{FW} \\
1492 \mathrm{RW}\end{array}$ & $\begin{array}{l}\text { AGAGTTTGATCMTGGCTCAG } \\
\text { CGGTTACCTTGTTACGACTT }\end{array}$ & 65 & $\sim 1400$ & {$[54]$} \\
\hline
\end{tabular}

FW, Forward Primer; RV, Reverse Primer; bp, base pair.

Table 2. Results of biochemical tests.

\begin{tabular}{|c|c|c|c|c|c|}
\hline Test & of bacte & tes & & & \\
\hline \multirow{2}{*}{ Gram Staining } & $19.3 \%$ & $38.7 \%$ & $25.8 \%$ & $12.9 \%$ & $3.2 \%$ \\
\hline & G-, rod & G-, rod & G-, rod & G-, rod & G-, rod \\
\hline Motility & + & - & + & + & + \\
\hline Indole & + & - & + & - & + \\
\hline Methyl Red & + & - & + & - & - \\
\hline Voges-Proskauer & - & + & - & + & + \\
\hline Citrate & - & + & + & + & + \\
\hline $\mathrm{H} 2 \mathrm{~S}$ production & - & - & - & - & - \\
\hline Lactose fermentation & + & + & + & + & + \\
\hline Perspective bacteria & E. coli & Klebsiella sp. & Kluyvera sp. & Enterobacter sp. & A. hydrophila \\
\hline
\end{tabular}

G-, Gram Negative; +, positive result; -, Negative result. 
rDNA could be the heat scale reaches blue area, on the other hand if sequences are different, heat scale will be directed to red region. This illustration showed how successful was 16S rDNA molecular barcode to differentiate between bacterial species as illustrated in (Figures 2 and 3).

\section{Detection of tet genes}

From PCR reaction, tetracycline resistant genes were detected in the selected thirty-one bacterial isolates. Six tet resistance determinants (tet $\mathrm{A}$, tet $\mathrm{B}$, tet $\mathrm{C}$, tet $\mathrm{D}$, tet $\mathrm{M}$ and tet $\mathrm{O}$ ) were tested, only three determinants (tet $\mathrm{A}$, tet $\mathrm{D}$ and tet $\mathrm{M}$ ) were detected. Two of the determinants were efflux pump genes (tet $\mathrm{A}$, tet $\mathrm{D})$ and one was ribosomal protection protein gene (tet $\mathrm{M})$ (Table 3).

The PCR fragment of tet A was $917 \mathrm{bp}$, whereas, the band of the positive isolates of tet $\mathrm{D}$ was at $787 \mathrm{bp}$. Additionally, the band of tet $\mathrm{M}$ for positive isolates was at $406 \mathrm{bp}$ (Figure 4).

Thirteen isolates out of the 31 (41.9\%) were carried tet A gene,
$74.2 \%$ (23 of 31) were carried tet $\mathrm{D}$ gene, while $12.9 \%$ (4 of 31) carried tet $\mathrm{M}$ gene. The tested tet $\mathrm{B}$, tet $\mathrm{C}$ and tet $\mathrm{O}$ were not detected (Table 4$)$. Twenty-one isolates $(67.7 \%)$ harbored a single tet gene; five isolates $(16.1 \%)$ were found to have two different tet genes, three isolates $(9.7 \%)$ harbored three different tet genes. Moreover, two isolates were not detected any type of the tested tet genes. It could be related to the other non-tested tet genes (Table 4 and 5). The maximum detected tet genes combination in some strains were three, tet (A, D and M) (Table 5).

\section{Sequencing and Alignment}

The partial nucleotide sequences of tet genes detected in our study and published sequences were found to be nearly identical to the entries for the different tet genes. Nucleotide sequence of tet genes for our isolates has been deposited in the National Center for Biotechnology Information GenBank under accession numbers represented in (Table 4).

Table 3. Identification of tetracycline resistant bacteria and detection of their tetracycline resistant genes.

\begin{tabular}{|c|c|c|c|c|c|c|c|c|}
\hline Isolate Code & Species & $\begin{array}{c}\text { CenBank } \\
\text { Accession no. }\end{array}$ & $\operatorname{tet} \mathbf{A}$ & tet $\mathbf{B}$ & tet $\mathrm{C}$ & tet $\mathbf{D}$ & tet $\mathrm{M}$ & tet 0 \\
\hline 1 & Kluyvera sp. & MH266225 & + & - & - & - & - & - \\
\hline 3 & Klebsiella sp. & MH266226 & + & - & - & - & - & - \\
\hline 4 & Kluyvera sp. & MH266227 & + & - & - & - & - & - \\
\hline 5 & Kluyvera sp. & MH266228 & + & - & - & - & - & - \\
\hline 7 & Enterobacter sp. & MH266229 & + & - & - & + & - & - \\
\hline 8 & Kluyvera sp. & MH266230 & - & - & - & + & - & - \\
\hline 10 & Enterobacter cloacae & MH266231 & - & - & - & + & - & - \\
\hline 11 & Klebsiella pneumoniae & MH266232 & + & - & - & - & - & - \\
\hline $11 \mathrm{~A}$ & Klebsiella sp. & MH266233 & - & - & - & + & - & - \\
\hline 12 & Escherichia coli & MH266234 & - & - & - & + & - & - \\
\hline 13 & Klebsiella pneumoniae & MH266235 & - & - & - & + & - & - \\
\hline 14 & Enterobacter sp. & MH266236 & - & - & - & + & - & - \\
\hline 15 & Atlantibacter hermannii & MH266237 & - & - & - & + & - & - \\
\hline 16 & Klebsiella pneumoniae & MH266238 & - & - & - & + & - & - \\
\hline 17 & Escherichia coli & MH266239 & - & - & - & + & - & - \\
\hline 19 & Escherichia coli & MH266240 & - & - & - & - & - & - \\
\hline 22 & Klebsiella pneumoniae & MH266241 & - & - & - & + & - & - \\
\hline 24 & Escherichia coli & MH266242 & + & - & - & + & + & - \\
\hline 32 & Kluyvera sp. & MH266243 & + & - & - & + & - & - \\
\hline 33 & Enterobacter cloacae & MH266244 & - & - & - & + & - & - \\
\hline 44 & Aeromonas hydrophila & MH266245 & - & - & - & + & - & - \\
\hline 50 & Klebsiella pneumoniae & MH266246 & - & - & - & + & - & - \\
\hline 70 & Escherichia coli & MH266247 & + & - & - & + & + & - \\
\hline 74 & Klebsiella sp. & MH266248 & + & - & - & + & - & - \\
\hline 79 & Kluyvera sp. & MH266249 & + & - & - & + & - & - \\
\hline 133 & Klebsiella pneumoniae & MH266250 & - & - & - & - & - & - \\
\hline 188 & Kluyvera sp. & MH266251 & + & - & - & + & + & - \\
\hline 127 & Klebsiella pneumoniae & MH266252 & - & - & - & - & + & - \\
\hline 77 & Klebsiella pneumoniae & MH423704 & - & - & - & + & - & - \\
\hline $1 \mathrm{~T}$ & Kluyvera sp. & MH423705 & - & - & - & + & - & - \\
\hline 119 & Klebsiella pneumoniae & MH469556 & + & - & - & + & - & - \\
\hline Total t* & 31 isolates & & 13 & - & - & 23 & 4 & - \\
\hline
\end{tabular}

${ }^{*}$, Number of positive detection. 
In the NJ Phylogenetic tree, it was divided in to two clusters, cluster I represented two groups, group I represented identified resistant bacteria contained tet $\mathrm{D}$ gene and group II represented identified resistant bacteria contained tet $\mathrm{A}$. Cluster II represented identified resistant bacteria contained tet $\mathrm{M}$.

The identified resistant bacteria that contained tet A gene was more closely related to identified resistant bacteria that contained tet $\mathrm{D}$ gene, while the identified resistant bacteria that contained tet
M gene was distantly related to identified resistant bacteria contained tet $\mathrm{A}$ and tet $\mathrm{D}$ (Figure 5).

MeMe tool analysis demonstrates the differentiation of the bacterial tet genes into three different subfamilies and the construction of every gene from different amino acid domains. This analysis was conducted by aligning different amino acid sequencing through CLUSTALW, MeMe tool to discover amino acid motif (proteins domians), scanMotif and TomTom to annotate different

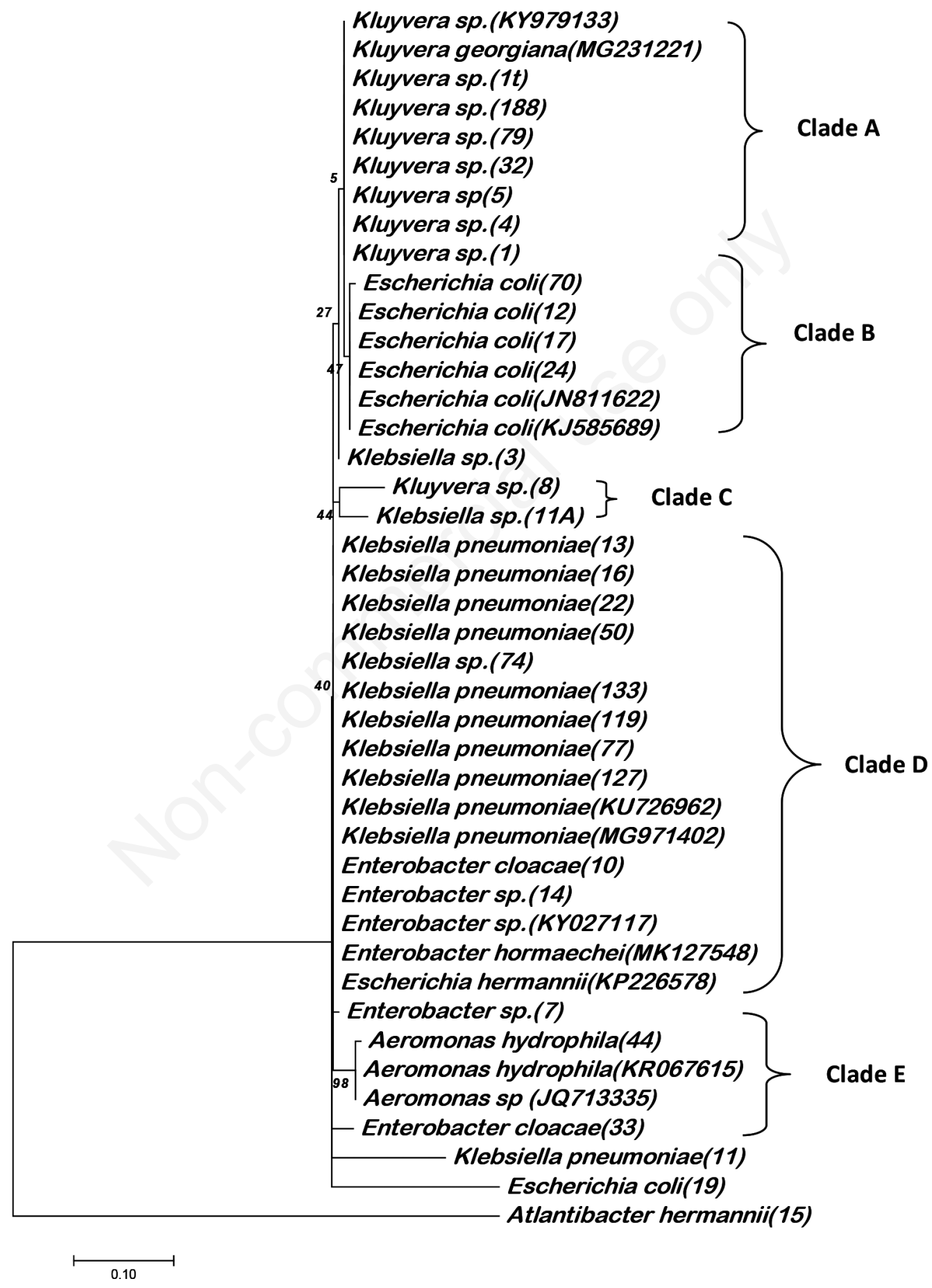

Figure 1. A phylogenetic tree of tetracycline-resistant bacterial isolates based on the nucleotide sequences of 16S rDNA genes. The scale bar shows the genetic distance. The number presented next to each node shows the percentage bootstrap value of 1000 replicates. 
amino acid motifs (domains). As illustrated in (Figure 6) both tet A and D have the Major Facilitator Superfamily protein MFS domain while tet $\mathrm{M}$ has different domain called p-loop NTPase.

\section{Discussion}

Antibiotic resistance is a major public health threat and the presence of resistant bacteria in water environment is an emerging concern globally. The high incidence of Antibiotic Resistant Bacteria (ARB) in this study may appear to be analogous to what was predicted by many previous studies such as the bad use of antibiotics and the lack of proper knowledge that increase the occurrence of ARB isolates in different water sources. The polluting of drinking water sources and the presence of antibiotic resistant bacteria increase the risk to human health. It is important to have detailed information regarding such issues.

This study encompassed detection of tetracycline resistant genes in thirty-one bacterial isolates from water samples of two locations El-Zamalek and Rod El-Farag of Cairo, Egypt. The results showed the presence of 250 bacterial isolates of which $(40 \%)$ were resistant to $(16 \mu \mathrm{g} / \mathrm{ml})$ tetracycline, which is an indication of tetracycline overuse. It is crucial to apply strict regula-
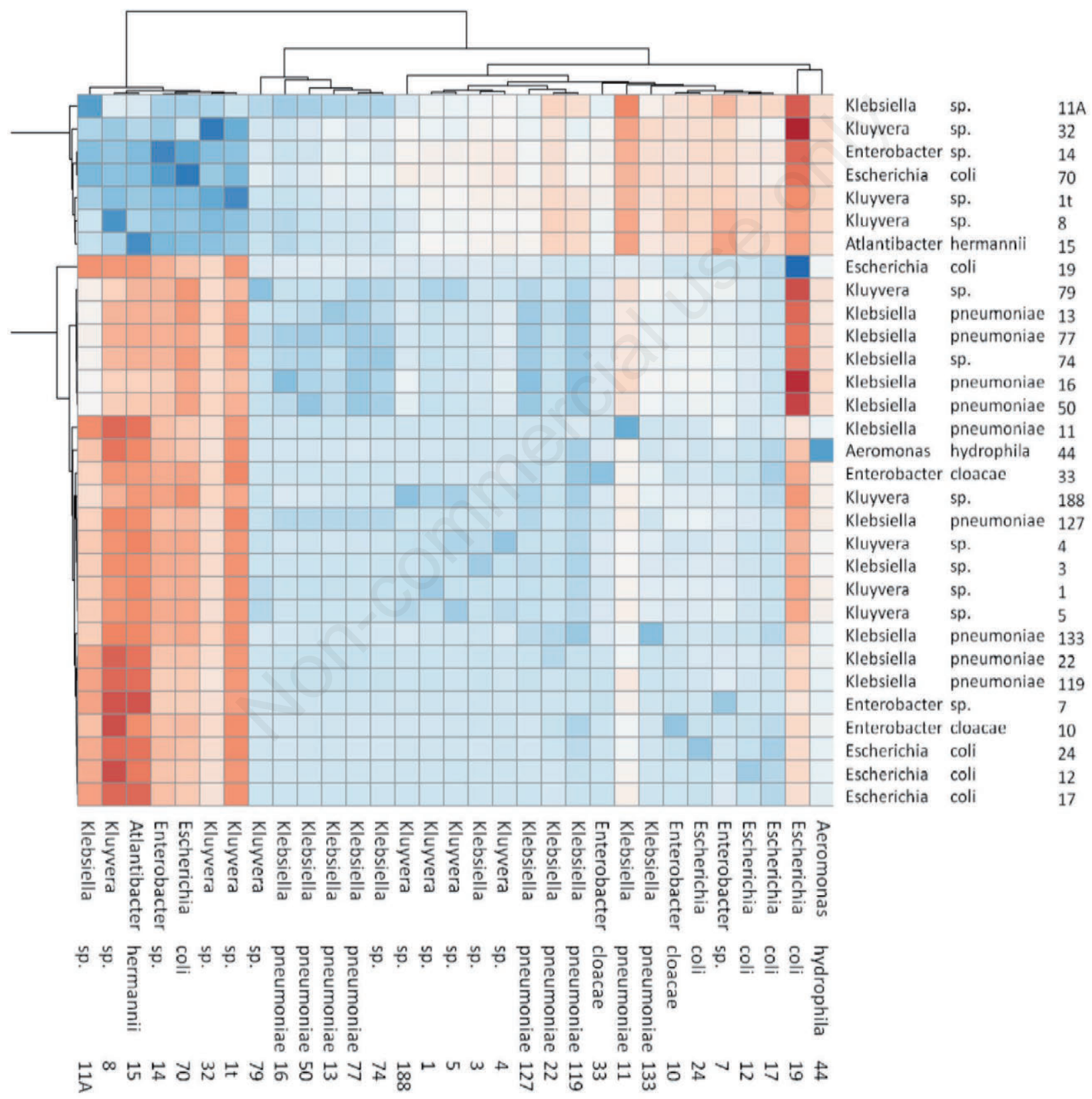

Figure 2. A heat map scale of the 31 identified bacterial isolates at the genus level revealed distinctions in diversity in the water samples. As close different $16 \mathrm{~S}$ rDNA could be the heat scale reaches blue area, on the other hand if sequences are different, heat scale will be directed to red region. 
tions and control of overuse in tetracycline and other antibiotics to reduce resistant strains. The amount of tetracycline used by animal and chicken farms has to be directed according to international restrictions and regulations. ${ }^{32}$

The presence of antibiotic resistant bacteria in different water sources is considered a public health alarm as drug resistant bacteria $^{33}$ even after chlorination that failed to control antimicrobial resistance. ${ }^{10}$ It could be transferred to humans through the drinking of contaminated water which then contributes to the spread and persistence of antibiotic resistant bacteria in the environment. ${ }^{34}$

Recently, tetracycline resistant genes have been widely selected as an indicator to evaluate ARGs contamination due to their clinical relevance, their high abundance and diversity in the aquatic environment and their predominance in fecal wastewater. ${ }^{35}$

The results of biochemical characterization were matched with the results of $16 \mathrm{~S}$ rDNA. Which the 31 isolates classified in to $38.7 \%$ Klebsiella, $25.8 \%$ kluyvera, E. coli 12.9\%, Enterobacter $3.2 \%$, Atlantibacter hermannii $3.2 \%$ and Aeromonas 3.2\%.
From PCR analysis, tet $\mathrm{A}$, tet $\mathrm{D}$ and tet $\mathrm{M}$ were found among the 31 tested isolates. Moreover, tet $\mathrm{A}$ and tet $\mathrm{D}$ were predominant genes $(41.9 \%$ and $74.2 \%$ respectively) that encode resistance by efflux mechanism. Tet $\mathrm{M}$, a gene that encoding ribosomal protection protein had the lowest detec rate $(12.9 \%)$. Our finding was compatible with who found that tet $\mathrm{A}$ was a main gene identified $(60 \%)$ in Enterobacteriaceae while tet $\mathrm{M}$ was not detected compared with our study that detected $(12.9 \%) .{ }^{34,36}$

The cause of such result is due to the different distribution patterns of tet genes in different environments which may be associated with bacterial compositions, antibiotic levels and horizontal gene transfer. ${ }^{18,37,38}$ In the previous studies conducted in the USA, it has been revealed that $4 \%$ of the tetracycline resistant isolates were positive for tet A, 19\% for tet B and 38\% for tet C. ${ }^{39}$ In another study in China, tet $A$ was the most prevalent ribosomal efflux gene (72\%) followed by tet $\mathrm{B}(15 \%)$ in tetracycline resistant $E$. coli strains. ${ }^{4}$

Tetracycline resistant genes have been found to be widespread in water environments; previous studies have demonstrated the

Table 4. tet genes GenBank accession numbers.

\begin{tabular}{|c|c|c|c|c|}
\hline Isolate Code & Species & $\begin{array}{c}\text { tet A } \\
\text { GenBank } \\
\text { Accession no. }\end{array}$ & $\begin{array}{c}\text { tet D } \\
\text { GenBank } \\
\text { Accession no. }\end{array}$ & $\begin{array}{c}\text { tet } \mathrm{M} \\
\text { GenBank } \\
\text { Accession no. }\end{array}$ \\
\hline 1 & Kluyvera sp. & МH477924 & - & - \\
\hline 3 & Klebsiella sp. & MH477925 & - & - \\
\hline 4 & Kluyvera sp. & MH477926 & - & - \\
\hline 5 & Kluyvera sp. & MH477927 & - & - \\
\hline 7 & Enterobacter sp. & MH477922 & MH397684 & - \\
\hline 8 & Kluyvera sp. & - & MH384389 & - \\
\hline 10 & Enterobacter cloacae & - & MH397686 & - \\
\hline 11 & Klebsiella pneumoniae & MH477923 & - & - \\
\hline $11 \mathrm{~A}$ & Klebsiella sp. & - & MH374913 & - \\
\hline 12 & Escherichia coli & - & МH374914 & - \\
\hline 13 & Klebsiella pneumoniae & - & MH374915 & - \\
\hline 14 & Enterobacter sp. & - & МH374916 & - \\
\hline 15 & Atlantibacter hermannii & - & MH374917 & - \\
\hline 16 & Klebsiella pneumoniae & - & МH374918 & - \\
\hline 17 & Escherichia coli & - & MH374919 & - \\
\hline 19 & Escherichia coli & - & - & - \\
\hline 22 & Klebsiella pneumoniae & - & MH384390 & - \\
\hline 24 & Escherichia coli & MH477918 & МH397687 & MH445512 \\
\hline 32 & Kluyvera sp. & MH477919 & MH384391 & - \\
\hline 33 & Enterobacter cloacae & - & MH397685 & - \\
\hline 44 & Aeromonas hydrophila & - & MH384388 & - \\
\hline 50 & Klebsiella pneumoniae & - & MH384393 & - \\
\hline 70 & Escherichia coli & MH477928 & MH384394 & MH445513 \\
\hline 74 & Klebsiella sp. & MH477929 & MH384395 & - \\
\hline 79 & Kluyvera sp. & MH477930 & MH397681 & - \\
\hline 133 & Klebsiella pneumoniae & - & - & - \\
\hline 188 & Kluyvera sp. & MH477920 & MH397683 & MH445515 \\
\hline 127 & Klebsiella pneumoniae & - & - & MH445514 \\
\hline 77 & Klebsiella pneumoniae & - & MH450231 & - \\
\hline $1 \mathrm{~T}$ & Kluyvera sp. & - & MH384392 & - \\
\hline 119 & Klebsiella pneumoniae & MH477921 & MH397682 & - \\
\hline Total & 31 isolates & 13 & 23 & 4 \\
\hline
\end{tabular}


abundance of tet $\mathrm{B}$, tet $\mathrm{C}$ and tet $\mathrm{D}$ in rivers impacted by anthropogenic influence and wastewater lagoons ${ }^{34}$ and tet $\mathrm{B}$, tet $\mathrm{C}$ and tet $\mathrm{M}$ in surface water. ${ }^{40}$ The presence of more than one tet resistant gene per isolate frequently occurred in the current study. Some of the isolates contained two genes $(16.1 \%)$ while some contained three genes $(9.7 \%)$ which is an indication of the overuse of tetracyclines. Such finding could be linked to the occurrence of those genes in an unidentified environmental isolate from the environment which are considered a reservoir and source of transfer to other bacteria of antibiotic resistant genes. The findings of the present study are supported by ${ }^{41}$ and $^{42}$ who also detected antibiotic resistant genes attributed to uncultured or unidentified soil bacteria. Tetracycline resistant bacteria isolated from water samples showed high variation and frequency of multiple tet genes. ${ }^{43}$

Many studies have proven the occurrence of more than one tetracycline resistant gene. ${ }^{44}$ Two tet genes (tet $\mathrm{D}$, tet $\mathrm{M}$ ) were found in strains of Aeromonas spp. But in our study, it carries only tet $\mathrm{D}$ compared to findings ${ }^{45}$ who reported that tet $\mathrm{D}$ and tet $\mathrm{M}$ genes were always present in association with other tet genes. In contrast, several authors reported the prevalence of efflux tet gene (tet D) in Aeromonas hydrophila isolated from fish pathogens. ${ }^{46} \mathrm{In}$ our study tet $\mathrm{B}$, tet $\mathrm{C}$ and tet $\mathrm{O}$ were not detected in any of the isolates. This finding showed close agreement with ${ }^{47}$ who declared that $53.85 \%$ isolates possessed one or more of the tested genes (tet $\mathrm{A}$, tet $\mathrm{B}$ ) whereas $46.15 \%$ isolates had no tested genes (tet $\mathrm{C}$ ). Our results confirmed that water contamination levels can be analyzed based on tetracycline resistant genes. ${ }^{48}$

The occurrence and persistence of tetracycline resistant bacteria and their resistance genes makes the situation even worse and more complicated. The results from the present study confirmed that water contamination levels can be analyzed based on tetracycline resistant genes. ${ }^{48}$

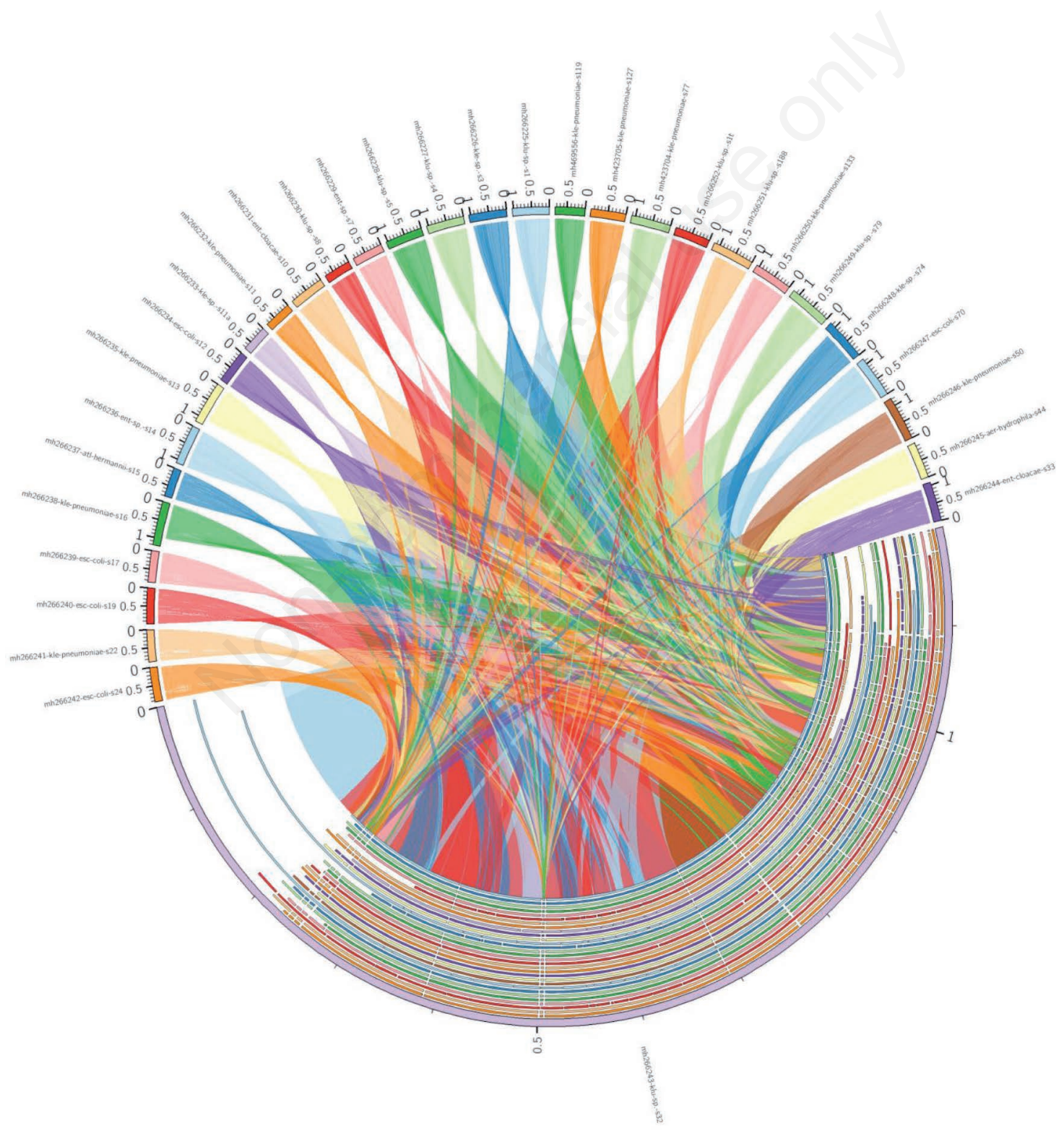

Figure 3. CIRCOS configuration visualizing data which illustrates nucleotide regions have a similarity to each other and sequences length of $16 \mathrm{~s}$ rDNA sequences. 


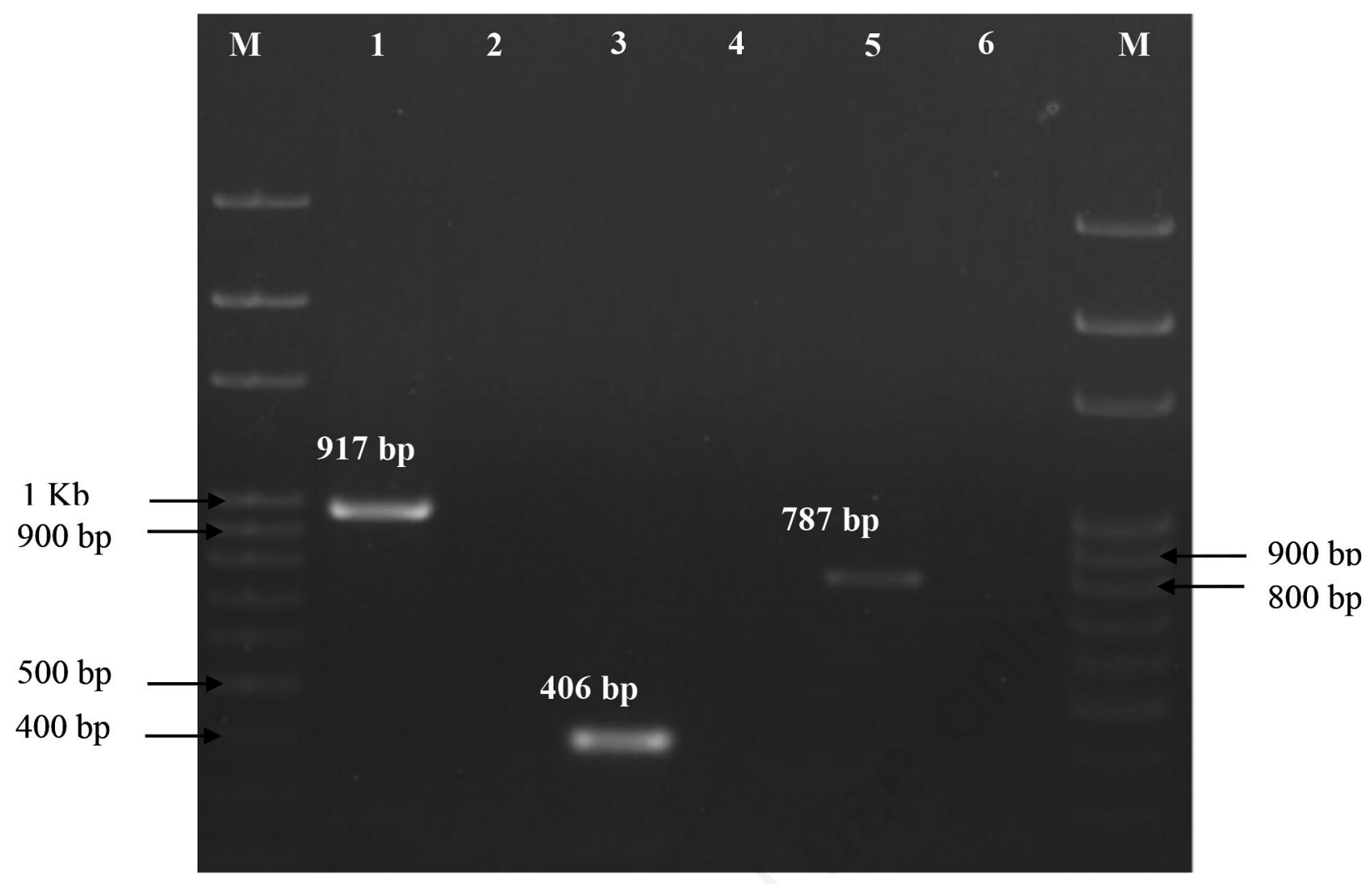

Figure 4. Gel electrophoresis band pattern of the amplified products of tet A, tet D and tet M. Lane M represents DNA ladder, lane 1 tet $\mathrm{A}$, lane 3 tet $\mathrm{M}$, lane 5 tet $\mathrm{D}$ lane 2,4,6 negative control for each set of primers.

Table 5. Distribution of tet genes in bacterial isolates.

\begin{tabular}{|c|c|c|}
\hline $\begin{array}{l}\text { One Determinant } \\
\mathrm{N}=21\end{array}$ & $\begin{array}{l}\text { Two Determinants } \\
\mathrm{N}=5\end{array}$ & $\begin{array}{l}\text { Three Determinants } \\
\mathrm{N}=3\end{array}$ \\
\hline Kluyvera sp. tet $\mathrm{A}$ & Enterobacter sp. tet A, D & Escherichia coli tet A, D, M \\
\hline Klebsiella sp. tet $\mathrm{A}$ & Kluyvera sp. tet A, D & Escherichia coli tet A, D, M \\
\hline Kluyvera sp. tet A & Klebsiella sp. tet A, D & Kluyvera sp. tet A, D, M \\
\hline Kluyvera sp. tet $\mathrm{A}$ & Kluyvera sp. tet A, D & \\
\hline Kluyvera sp. tet D & Klebsiella pneumoniae tet $\mathrm{A}, \mathrm{D}$ & \\
\hline \multicolumn{3}{|l|}{ Enterobacter cloacae tet $\mathrm{D}$} \\
\hline \multicolumn{3}{|l|}{ Klebsiella pneumoniae tet $\mathrm{A}$} \\
\hline \multicolumn{3}{|l|}{ Klebsiella sp. tet D } \\
\hline \multicolumn{3}{|l|}{ Escherichia coli tet $\mathrm{D}$} \\
\hline \multicolumn{3}{|l|}{ Klebsiella pneumoniae tet $\mathrm{D}$} \\
\hline \multicolumn{3}{|l|}{ Enterobacter sp. tet D } \\
\hline \multicolumn{3}{|l|}{ Atlantibacter hermannii tet D } \\
\hline \multicolumn{3}{|l|}{ Klebsiella pneumoniae tet D } \\
\hline \multicolumn{3}{|l|}{ Klebsiella pneumoniae tet $\mathrm{D}$} \\
\hline \multicolumn{3}{|l|}{ Escherichia coli tet D } \\
\hline \multicolumn{3}{|l|}{ Klebsiella pneumoniae tet $\mathrm{D}$} \\
\hline \multicolumn{3}{|l|}{ Enterobacter cloacae tet $\mathrm{D}$} \\
\hline \multicolumn{3}{|l|}{ Aeromonas hydrophila tet D } \\
\hline \multicolumn{3}{|l|}{ Klebsiella pneumoniae tet $\mathrm{D}$} \\
\hline \multicolumn{3}{|l|}{ Klebsiella pneumoniae tet $\mathrm{M}$} \\
\hline Kluyvera sp.tet D & & \\
\hline
\end{tabular}




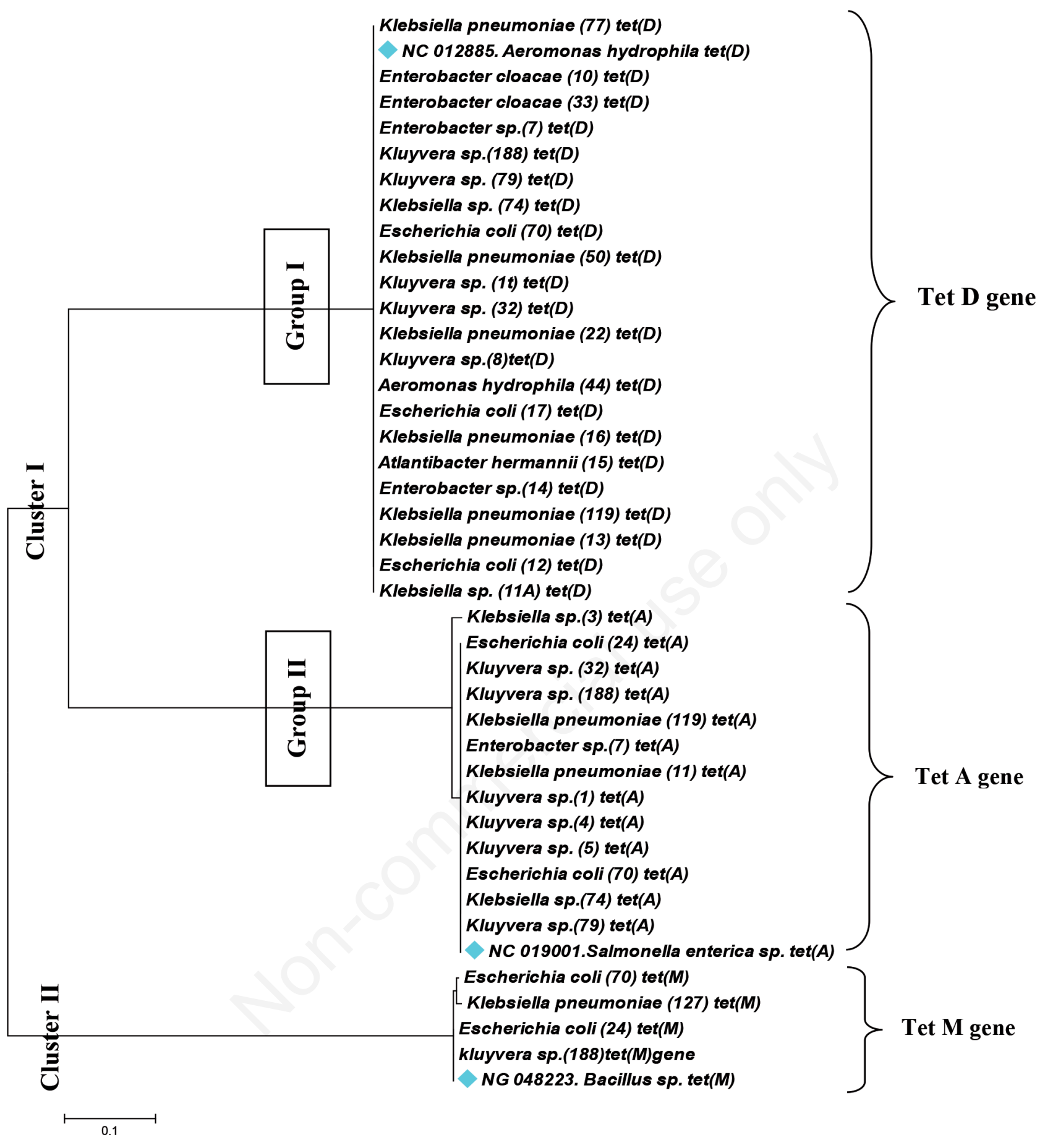

Figure 5. Unrooted phylogram showing the genetic distances between tet-ARGs of tet $\mathrm{D}$; tet $\mathrm{A}$ and tet $\mathrm{M}$ sequences (neighbor-joining), using MEGA7.The analysis involved 42 amino acid sequences. All positions containing gaps and missing data were eliminated. Alignment of the sequences was done with CLUSTALW, bootstrap values (in percent) are calculated from 1000 resamplings. The GenBank accession numbers of the reference bacteria are presented in dotes.

\section{Conclusions}

In the present study identification of tetracycline resistant bacteria is confirmed by the presence of tet $\mathrm{A}, \mathrm{D}$, and $\mathrm{M}$ genes in the resistance bacterial isolates from Nile River which reflect that
Tetracycline Resistance Bacteria (TRB) and Tetracycline Resistance Genes (TRGs) could be used as indicators of the microbiological quality of river waters threatened by man-made pollution. Our finding confirmed that water contamination levels can be analyzed based on tetracycline resistant genes. Simultaneous monitoring in water samples from the river system is therefore recom- 


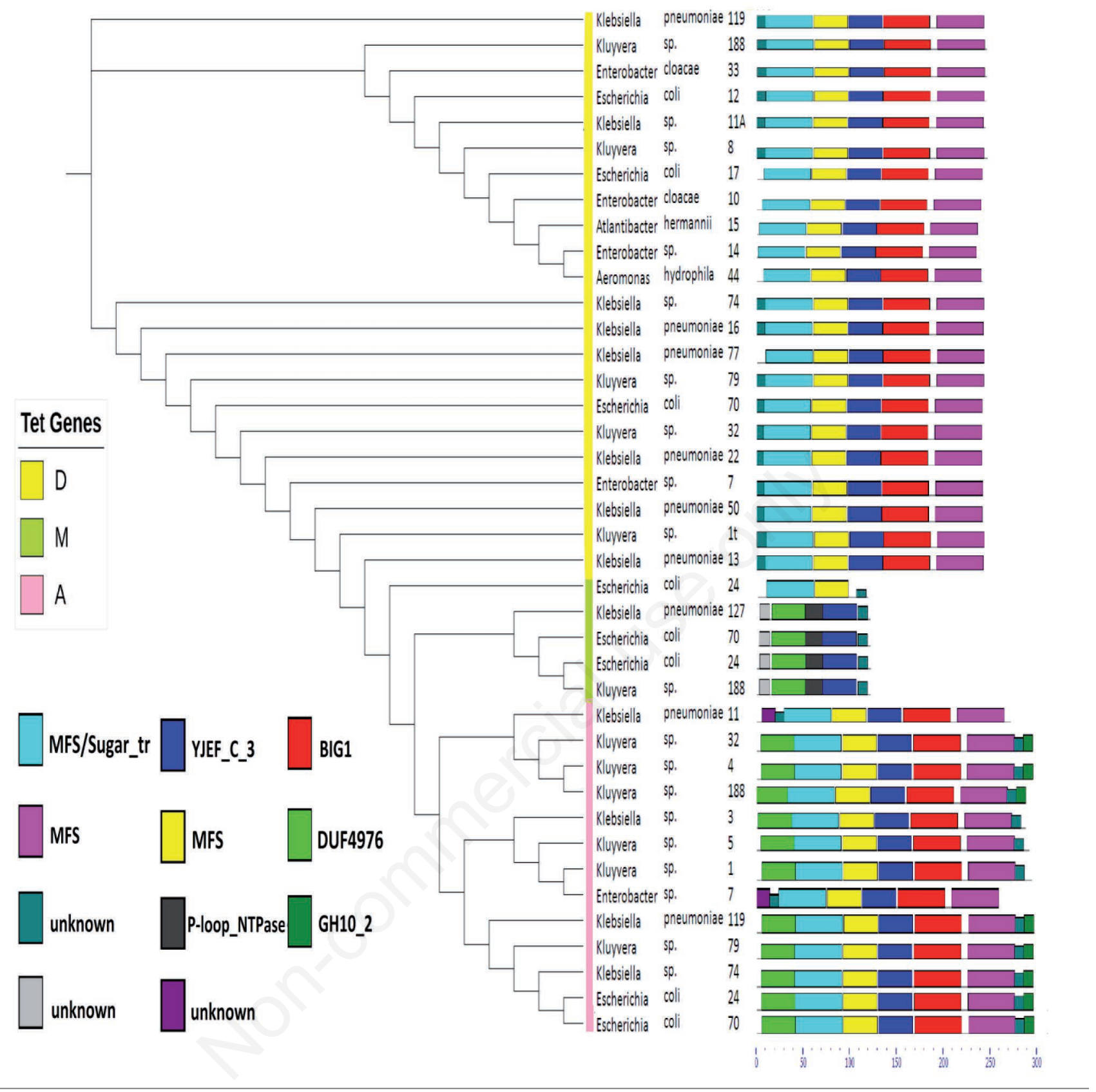

Figure 6. The phylogenetic tree by adding domains and motifs of the three tet genes A, D and M.

mended through improvement of risk assessment management strategies. It is necessary to explore a link between ARGs in the natural water and public health and establish an appropriate risk assessment model to evaluate their hazardous for human.

\section{References}

1. Faria C, Vaz-Moreira I, Serapicos E, et al. Antibiotic resistance in coagulase negative staphylococci isolated from wastewater and drinking water. Sci. Total Environ 2009;407:3876-82.

2. Guerin E, Cambray G, Sanchez-Alberola N, et al. The SOS response controls integron recombination. Science 2009;324:1034.

3. Berglund B. Environmental dissemination of antibiotic resistance genes and correlation to anthropogenic contamination with antibiotics. Infect Ecol Epidemiol 2015;5:28564.

4. Wang R, Wang A, Wang J. Antibiotic resistance monitoring in heterotrophic bacteria from anthropogenic-polluted seawater and the intestines of oyster Crassostrea hongkongensis. Ecotoxicol Environ Saf 2014;109:27-31.

5. Peng S, Wang Y, Zhou B, Lin X. Long-term application of fresh and composted manure increase tetracycline resistance in the arable soil of Eastern China. Sci Total Environ 2015;506:279-86. 
6. Zhang Y, Marrs C, Simon C, Xi C. Wastewater treatment contributes to selective increase of antibiotic resistance among Acinetobacter spp. Sci Total Environ 2009;407:3702- 6.

7. Dang H, Ren J, Song L, et al. Dominant chloramphenicolresistant bacteria and resistance genes in coastal marine waters of Jiaozhou Bay, China. World J Microbiol Biotechnol 2008;24:209-17.

8. Łuczkiewicz A, Jankowska K, Fudala-Ksiazek S, OlanczukNeyman K. Antimicrobial resistance of fecal indicators in municipal wastewater treatment plant. Water Res 2010;44:5089-97.

9. Moore J, Moore P, Millar B, el al. The presence of antibiotic resistant bacteria along the River Lagan. Agricultural Water Management 2010;98:217-21.

10. Yuan Q, Guo M, Yang J. Fate of Antibiotic Resistant Bacteria and Genes during Wastewater Chlorination: Implication for Antibiotic Resistance Control. PLoS ONE 2015;10.

11. Guo M, Yuan Q, Yang J. Distinguishing effects of ultraviolet exposure and chlorination on the horizontal transfer of antibiotic resistance genes in municipal wastewater. Environm sci technol 2015;49:5771-8.

12. Czekalski N, Sigdel R, Birtel J, el al. Does human activity impact the natural antibiotic resistance background? Abundance of antibiotic resistance genes in 21 Swiss lakes. Environ Int 2015;81:45-55.

13. Mulamattathil S, Bezuidenhout C, Mbewe M, Ateba C. Isolation of environmental bacteria from surface and drinking water in Mafikeng, South Africa, and characterization using their antibiotic resistance profiles. J Pathog 2014;2014:371208.

14. Jia S, Zhang X, Miao Y, el al. Fate of antibiotic resistance genes and their associations with bacterial community in livestock breeding wastewater and its receiving river water. Water Res 2017;124:259-68.

15. Marti E, Variatza E, Balcazar J. The role of aquatic ecosystems as reservoirs of antibiotic resistance. Trends Microbiol 2014;22:36-41.

16. Roberts M. Update on acquired tetracycline resistance genes. FEMS Microbiol Lett 2005;245:195-203.

17. Yang Y, Song W, Lin H, el al. Antibiotics and antibiotic resistance genes in global lakes: A review and meta-analysis. Environ Int 2018;116:60-73.

18. Chopra I, Roberts M. Tetracycline antibiotics: mode of action, applications, molecular biology, and epidemiology of bacterial resistance. Microbiol Mol Biol Rev 2001;65:232-60.

19. Xu J, Xu Y, Wang $\mathrm{H}$, el al. Occurrence of antibiotics and antibiotic resistance genes in a sewage treatment plant and its effluent-receiving river. Chemosphere 2015;119:1379-85.

20. Harnisz M, Korzeniewska E, Gołaś I. The impact of a freshwater fish farm on the community of tetracycline-resistant bacteria and the structure of tetracycline resistance genes in river water. Chemosphere 2015;128:134-41.

21. Roberts, M. Tetracycline resistance determinants: mechanisms of action, regulation of expression, genetic mobility, and distribution. FEMS Microbiol Rev 1996;19:1-24.

22. Li C, Jiang C, Wu Z, el al. Diversity of antibiotic resistance genes and encoding ribosomal protection proteins gene in livestock waste polluted environment. J Environ Sci Health B 2018;53:423-33.

23. American Public Health Association, American Water Works Association, Water Pollution Control Federation, Water Environment Federation. Standard methods for the examination of water and wastewater (Vol. 2). American Public Health Association, 1915.
24. Wayne P. CLSI. Performance Standards for Antimicrobial Susceptibility Testing; Twenty-Fifth Informational Supplement. CLSI Document M100-S25, Clinical and Laboratory Standards Institute, 2015.

25. Diagnostics B. Difco ${ }^{\mathrm{TM}} \& \mathrm{BBL}^{\mathrm{TM}}$ Manual, Manual of Microbiological Culture Media; 2009.

26. Rice A, Baird E, Eaton R. APHA 2017 Standard Methods for Examination of Water and Wastewater (Washington: American Public Health Association, American Water Works Association, Water Environment Federation ISBN), 2017.

27. Altschul S, Gish W, Miller W, el al. Basic local alignment search tool. J Mol Biol 1990;215:403-10.

28. Sievers F, Higgins D. Clustal Omega, accurate alignment of very large numbers of sequences. In Multiple sequence alignment methods. Humana Press, Totowa, NJ, 2014. pp 105-116.

29. Kumar S, Stecher G, Tamura K. MEGA7: Molecular Evolutionary Genetics Analysis version 7.0 for bigger datasets. Molecul Biol Evol 2016;33:1870-4.

30. Krzywinski M, Schein J, Birol I, el al. Circos: an information aesthetic for comparative genomics. Geonom Res 2009;19:1639-45.

31. Backman T, Girke T. systemPipeR: NGS workflow and report generation environment. BMC Bioinf 2016;17:388.

32. Franco B, Martínez M, Rodríguez M, Wertheimer A. The determinants of the antibiotic resistance process. Infect Drug Resist 2009;2:1-11.

33. Vaz-Moreira I, Nunes O, Manaia C. Bacterial diversity and antibiotic resistance in water habitats: searching the links with the human microbiome. FEMS Microbiol Rev 2014;38:761-78.

34. Tao R, Ying G, Su H, el al. Detection of antibiotic resistance and tetracycline resistance genes in Enterobacteriaceae isolated from the Pearl Rivers in South China. Environ Poll 2010;158:2101-9.

35. Chen B, Hao L, Guo X, el al. Prevalence of antibiotic resistance genes of wastewater and surface water in livestock farms of Jiangsu Province, China. Environ Sci Pollut Res 2015;22:13950-9.

36. Zhang C, Du C, Xu H, el al. Occurrence of tetracycline-resistant fecal coliforms and their resistance genes in an urban river impacted by municipal wastewater treatment plant discharges. J Environ Sci Health 2015;50:744-9.

37. Levy S, Marshall B. Antibacterial resistance worldwide: causes, challenges and responses. Nat Med 2004;10:S122- 9.

38. Martinez J. Environmental pollution by antibiotics and by antibiotic resistance determinants. Environ Pollut 2009; 157:2893-902.

39. Ibekwe A, Murinda S, Graves AK. Genetic Diversity and Antimicrobial Resistance of Escherichia coli from Human and Animal Sources Uncovers Multiple Resistances from Human Sources. PLoS ONE 2011;6:20819.

40. Stoll C, Sidhu J, Tiehm A, Toze S. Prevalence of clinically relevant antibiotic resistance genes in surface water samples collected from Germany and Australia. Environ Sci Technol 2012;46:9716-26.

41. Adesoji A, Ogunjobi A, Olatoye I, Douglas R. Prevalence of tetracycline resistance genes among multi-drug resistant bacteria from selected water distribution systems in southwestern Nigeria. Ann Clin Microbiol Antimicrob 2015;14:35.

42. Riesenfeld C, Goodman R, Handelsman J. Uncultured soil bacteria are reservoir of new antibiotic resistance gene. Environ Microbiol 2004;6:981-9.

43. Al-Bahry S, Al-Sharji N, Yaish M, et al. Diversity of Tetracycline Resistant Genes in Escherichia coli from Human 
and Environmental Sources. The Open Biotec J 2016;10: 289-300.

44. Bryan A, Shapir N, Sadowsky M. Frequency and distribution of tetracycline resistance genes in genetically diverse, nonselected, and non-clinical Escherichia coli strains isolated from diverse human and animal sources. Appl Environ Microbiol 2004; 70: 2503-7.

45. Jacobs L, Chenia H. Characterization of integrons and tetracycline resistance determinants in Aeromonas spp. isolated from South African aquaculture systems. Int J Food Microbiol 2007;114:295-306.

46. Al-Charrakh A, Al-Shalah L. Prevalence of efflux genes and ribosomal protection genes among tetracycline-resistant Aeromonas hydrophila isolated from diarrheic patients in Iraq. BLDE University. J Health Sci 2017;2:1.

47. Dutta A, Jalal M, Nath S, el al. Multi-Drug Resistance Pattern of Escherichia coli Isolated from Hospital Effluent and Determination of Tetracycline Resistance Gene. J Inf Mol Biol 2017;4:49-53.

48. Chen B, Liang X, Huang X, el al. Differentiating anthropogenic impacts on ARGs in the Pearl River Estuary by using sui gene indicators. Water Res. 2013;47:2811-20.

49. Guardabassi L, Dijkshoorn L, Collard J, et al. Distribution and in-vitro transfer of tetracycline resistance determinants in clin- ical and aquatic Acinetobacter strains. J Med Microbiol 2000;49:929-36.

50. Aminov R, Garrigues-Jeanjean N, Mackie R. Molecular ecology of tetracycline resistance: development and validation of primers for detection of tetracycline resistance genes encoding ribosomal protection proteins. Appl Environ Microbiol 2001;67:22-32.

51. Aminov R, Chee-Sanford J, Garrigues N, el al. Development, validation, and application of PCR primers for detection of tetracycline efflux genes of gram-negative bacteria. Appl Environ Microbiol 2002;68:1786-93.

52. Marshall B, Tachibana C, Levy S. Frequency of tetracycline resistance determinant classes among lactose-fermenting coliforms. Antimicrob Agents Chemother 1983;24:835-40.

53. Ng L, Martin I, Alfa M, Mulvey M. Multiplex PCR for the detection of tetracycline resistant genes. Mol Cell Probes 2001;15:209-15.

54. Du J, Ren H, Geng J, el al. Occurrence and abundance of tetracycline, sulfonamide resistance genes, and class 1 integron in five wastewater treatment plants. Environ Sci Pollut Res Int 2014;21:7276-84.

55. Eden P, Schmidt T, Blakemore R, Pace N. Phylogenetic analysis of Aquaspirillum magnetotacticum using polymerase chain reaction-amplified 16S rRNA-specific DNA. Int J Syst Evol Microbiol 1991;41:324-25. 